\title{
Trends, Determinants and Health Risks of Adolescent Fatherhood in Sub-Saharan Africa
}

\author{
Emmanuel O. Amoo ${ }^{1}$, Angie Igbinoba ${ }^{2}$, David Imhonopi ${ }^{3}$, Olufunmilayo $O$. \\ Banjo $^{4}$, Chukwuedozie K. Ajaero ${ }^{5}$, Joshua O. Akinyemi ${ }^{6}$, David Igbokwe ${ }^{7}$, \\ Lukman B. Solanke ${ }^{4}$
}

OPEN ACCESS

Citation: Amoo E. O., Igbinoba A., Imhonopi D, Banjo O. O, Ajaero C. K., Akinyemi J. O., Igbokwe D., Solanke L. B. Trends, Determinants and Health Risks of Adolescent Fatherhood in subSaharan Africa. Ethiop $J$ Health Sci.2017;28(4):433.

doi:http://dx.doi.org/10.4314/ejhs.v28i4.9

Received: February 13, 2018

Accepted: February 20,2018

Published: July 1, 2018

Copyright: (C) 2018 Amoo E., et al . This is an open access article distributed under the terms of the Creative Commons Attribution License, which permits unrestricted use, distribution, and reproduction in any medium, provided the original author and source are credited.

Funding: Nil

Competing Interests: The authors declare that this manuscript was approved by all authors in its form and that no competing interest exists.

Affiliation and Correspondence:

${ }^{1}$ Demography and Social Statistics,

Covenant University, Ota, Nigeria

${ }^{2}$ Mass Communication Department,

Covenant University, Ota,

Nigeria

${ }^{3}$ Department of Sociology, Covenant

University, Ota, Nigeria

${ }^{4}$ Department of Demography and

Social Statistics, Obafemi

Awolowo University, Ile-Ife, Nigeria

${ }^{5}$ Department of Geography, University of Nigeria, Nsukka

${ }^{6}$ Department of Psychology, Covenant University, Ota, Nigeria

${ }^{7}$ Department of Demography and

Social Statistics, Obafemi

Awolowo University, Ile-Ife, Nigeria

*Email:emma.amoo@covenantunivers

ity.edu.ng

\section{ABSTRACT}

BACKGROUND: This study examined the trends, determinants and health risks of adolescent fatherhood in three selected African countries where adolescent-girl pregnancy/motherhood are decried but with permissive male sexual latitude.

METHODS: Adolescent male data were extracted from the malerecode datasets of Demographic Health Survey (2000-2014) for Nigeria, Ethiopia and Zambia. The surveys were grouped into 3Waves: (2000-2004); (2005-2008) and (2011-2014). The study employed descriptive and binary logistics that tested the log-odds of adolescent fatherhood with respect to selected sexual behaviour indices, and individual and shared demographic variables.

RESULTS: The results revealed that the number of lifetimesexual-partners among the boys is $\geq 2$. The likelihood of adolescent fatherhood is positively associated with increasing age at first cohabitation and multiple sexual partnerships $(\geq 2)$ having $O R=1.673$ and $O R=1.769$ in $2005 / 2008$ and $2011 / 2014$ respectively. Adolescents who had attained tertiary education, and engaged in professional and skilled jobs were $0.313,0.213$ and 0.403 times (respectively) less likely to have ever-fathered a child. The positive association between rural place of residence and adolescent fatherhood in the past shifted to urban residents in 2011/2014.

CONCLUSION: The study concludes that early sexual activities and cohabitation are common among male adolescents among the countries of study. The authors recommend discouragement of boy-girl cohabitation, increasing access to higher education and job opportunities in order to stem boy-fatherhood incidence in the study locations and, by extension, other countries in sub-Saharan Africa.

KEYWORDS: Adolescent fatherhood, sexual behaviour, trends, determinants, health risks, lifetime-sexual-partners 


\section{INTRODUCTION}

The increasing waves of risky sexual behaviour among adolescents has been documented worldwide, especially with high level of premarital sex, non-use or rare-use of condom including multiple sexual partners in sub-Saharan countries (1-4). The consequences of these behaviours are unwanted pregnancies, early motherhood, early fatherhood and STIs/HIV, among other trajectories $(2,4-7)$. While adolescent pregnancies and child motherhood have been decried over the years, not much attention has been placed on adolescent fatherhood and circumstances that are influencing this event, especially in sub-Sahara Africa. In this region, masculinity is supreme and men's sexuality landscape is relatively perforated with unchecked measures of sex outside marriage $(8-11)$. There is generally sexual latitude for men, perhaps because of the patriarchal system in the region. Specifically, in countries like Nigeria and Ghana, pregnancy in school terminates school attendance (12), but boy-fatherhood is often celebrated even within the family(6). While there are numerous studies on teen and adolescent pregnancy, and huge resources devoted to strategies to stem the incidence, there is relative silence on issues related to boy fatherhood, not only among the researchers, but also in terms of public interventions.

Among the boys worldwide, sexual knowledge and demonstration of high risk sexual behaviour are becoming more rampant. In subSaharan Africa, over $20 \%$ of adolescent who have ever had sex also have multiple sexual partners $(13,14)$. A study in Ethiopia reported that $55 \%$ out of 40 adolescent boys interviewed were already in sexual relationships (1). Another study reported that out of 145 adolescents who had pre-marital sex, $70 \%$ were male adolescents (2). In Nigeria, reports have shown that almost $35 \%$ of the 200 teenagers interviewed had fathered at least a child or impregnated a girl $(6,15)$. The majority of the adolescent boys today brag more about their sexual prowess and strive to acquire sex skills than in pre- $21^{\text {st }}$ century (1). As noted also, the mean and median ages of sexual initiation for adolescent boys are as low as 14.8 and 15 years $(12,16)$, and currently, virtually all adolescents are more exposed to sexual information on media than in pre- 21 century.

In most cases, sexual activities are male initiated or mostly influenced by men $(17,18)$. Also, Africa runs patriarchal and patrilineal systems where men are supreme (19), and their decisions, comportment and supports are akin to women sexual outcomes $(19,20)$. Thus, the solutions to myriads of sexuality problems might be a mirage if adequate attention is not given to the male factor. In sub-Saharan Africa, teen-girl pregnancy is often frowned at, but there is relative general tolerance of teen/adolescent boys' sexual behaviour, in addition to little or scanty literature on teen-fatherhood or adolescent fathers. This study therefore attempted to provide answers to few boggling questions on teenage fatherhood. What are prevalence rates of adolescent fatherhood in countries of sub-Sahara Africa? What are the factors responsible for this? Continuous identification of the drivers of adolescent fatherhood could help in curbing the challenges of early fatherhood and early pregnancy. This study is crucial because there is father-factor in almost every aspect of demographic challenges worldwide. Baby-fathers could also impose limitations on both the child/mother care and their future.

\section{METHODS AND MATERIALS}

Research design: The study used male-recode datasets of Demographic Health Survey (20002014) for Nigeria, Ethiopia and Zambia. The surveys were grouped into 3-waves: wave 1: 2000, 2002, 2003; wave 2: 2005, 2007, 2008 and waves 3: 2011, 2013, 2014. Ethiopia's data consisted of 2000, 2005 and 2011 datasets; Nigeria's datasets included 2003, 2008 and 2013 while Zambia's set of data featured 2002, 2007 and 2014. The data for 2001, 2006 and 2012 are missing from the data analyzed for the three sub-Saharan African countries. The files in each wave were grouped together and then combined into a single file. All data were weighted to ensure representation, and analyses were split by countries and by waves to show the trends across the years and for different countries.

DOI: http://dx.doi.org/10.4314/ejhs.v28i4.9 
Data and measurements: Adolescent father is conceptualized as a young male still under 24 years of age who has fathered at least a child or responsible for the procreation of an offspring regardless of the age of the woman $(6,21,22)$. Kiernan described a young father as a man who became a father before the age of 22 (23). Therefore, respondents were classified into two age groups: $\leq 19$ years $=1$ and 20-24 $=2$. Most available demographic variables related to adolescents were analyzed including the selected indicators of their sexual behaviour and parenthood. Selected sexual behaviour indicators used included age at first sex (age at which the man first experienced sexual intercourse) recoded as ( $\leq 19$ years, 20-24). The number of sexual partners was captured as $0=$ none, $1=$ only one and, 2 and above $=3$; condom use: if the respondent reported using condom in the last sex measured as Yes $=1$ or No $=0$. The frequency of union (i.e. union turnover) describes the number of times the respondents marries or engages in sexual union (only once $=1, \geq 2$ times $=2$ ) and transactional sex: whether the man has ever paid for sex in the last 12 months (Yes or No). The selected sexual behaviour indicators were as defined in the Integrated Demographic Health Survey Data Descriptions and also constituted part of independent variables $(13,24,25)$. The dependent variable is ever fathered at least a child, generated from the number of children ever fathered $(0=$ never; one and above $=1)$.

Data analysis: The study employed descriptive analysis (frequency tables with means and median statistics) to explore the trends and patterns of adolescent fatherhood while the multivariate analysis illustrated the determinants. The trends specifically investigated the direction of change in the determinants of adolescent fatherhood, while the patterns illustrate the sequence in adolescent fatherhood in the countries selected. In the multivariate analysis, we used the binary logistic regression to test the log of odds of adolescent fatherhood with respect to demographic characteristics and selected indices of sexual behaviour. The multivariate specifically measures the responsiveness of adolescent fatherhood to demographic and sexual indices of the adolescent in both 2005/2008 and 2011/2014.

Ethical considerations: The data used in this study were secondary data collated by MEASURES DHS, ICF Macro, and Calverton, Maryland, USA. The data were made available with the respondents identifiers completely removed. The survey exercises and the data were approved by Institutional Review Board of ICF Macro and also by country-specific ethics-related committees. International standards of data collections were duly employed and all participants gave informed consent before their participation. Information collected was also accorded the right to confidentiality. For this study, the lead author registered and applied for the use of the data and adequate permission was given before the data were downloaded and analyzed.

\section{RESULTS}

Background information about respondents: The selected demographic variables analyzed included education, religion and occupation. The result revealed that Ethiopia recorded the highest percentage $(36.0 \%)$ of adolescents who had no formal education. The proportion without formal education in Zambia is $4.0 \%$ lower than that of Nigeria (10.6\%) (Table 1). The proportion of adolescents with secondary education was $60.8 \%$, $37.8 \%$ and $23.6 \%$ in Nigeria, Zambia and Ethiopia, respectively. While the proportion of adolescent increased from primary to secondary education level in Nigeria, the opposite was the case for Ethiopia and Zambia. The proportions in tertiary levels were as low as $1.4 \%, 1.2 \%$ and $6.2 \%$ in Ethiopia, Zambia and Nigeria respectively. Ethiopia and Zambia recorded a decline in 'no formal education' category in wave 2 and 3 while Nigeria consistently recorded increase in this category among the adolescents.

DOI: http://dx.doi.org/10.4314/ejhs.v28i4.9 
Table 1: Selected Socio-demographic characteristics of Adolescents as at 2014

\begin{tabular}{|c|c|c|c|c|c|c|c|c|c|}
\hline \multirow[b]{2}{*}{ Selected variables } & \multicolumn{3}{|c|}{$2000-2004$} & \multicolumn{3}{|c|}{$2005-2008$} & \multicolumn{3}{|c|}{ 2011-2014 } \\
\hline & Ethiopia & Nigeria & Zambia & Ethiopia & Nigeria & Zambia & Ethiopia & Nigeria & Zambia \\
\hline \multicolumn{10}{|l|}{ Residence } \\
\hline Urban & 29.1 & 45.6 & 33.0 & 29.9 & 33.6 & 48.2 & 30.2 & 41.5 & 49.2 \\
\hline Rural & 70.9 & 54.4 & 67.0 & 70.1 & 66.4 & 51.8 & 69.8 & 58.5 & 50.8 \\
\hline \multicolumn{10}{|l|}{ Education } \\
\hline No formal Education & 35.8 & 10.6 & 4.0 & 24.3 & 14.7 & 2.3 & 14.8 & 15.0 & 1.7 \\
\hline Primary Education & 40.0 & 22.4 & 58.7 & 40.9 & 14.5 & 44.8 & 61.6 & 11.8 & 34.9 \\
\hline Secondary Education & 23.0 & 60.9 & 36.3 & 32.2 & 64.3 & 50.7 & 14.5 & 66 & 60.4 \\
\hline Higher Education & 1.2 & 6.2 & 1.0 & 2.7 & 6.5 & 2.2 & 9.1 & 7.2 & 3.0 \\
\hline \multicolumn{10}{|l|}{ Religion } \\
\hline Christianity & 48.5 & 33.3 & 97.3 & 50.5 & 55.1 & 98 & 45.7 & 52.9 & 98.5 \\
\hline Islam & 12.6 & 21.8 & 0.4 & 15.3 & 43.6 & 0.4 & 16.0 & 46.1 & 0.5 \\
\hline Others (Traditional) & 38.9 & 44.9 & 2.3 & 34.2 & 1.3 & 1.7 & 38.3 & 0.9 & 0.9 \\
\hline \multicolumn{10}{|l|}{ Wealth Status } \\
\hline Poor wealth status & na & 33.7 & na & 32.6 & 36.2 & 27.7 & 32.1 & 32.8 & 30.5 \\
\hline Middle wealth status & na & 18.8 & na & 13.6 & 21.5 & 19.5 & 15.8 & 22.4 & 21.7 \\
\hline Rich wealth status & na & 47.5 & na & 53.8 & 42.3 & 52.9 & 52.1 & 44.8 & 47.8 \\
\hline \multicolumn{10}{|l|}{ Marital status } \\
\hline Never in union & 87.7 & 92.5 & 85.3 & 86.9 & 91.3 & 87.3 & 86.1 & 93.5 & 89.5 \\
\hline $\begin{array}{l}\text { Married/Living with } \\
\text { partner }\end{array}$ & 10.1 & 6.6 & 12.9 & 11.8 & 8.3 & 11.5 & 12.4 & 6.1 & 9.5 \\
\hline Others (e.g. separated) & 2.2 & 0.9 & 1.8 & 1.3 & 0.4 & 1.2 & 1.5 & 0.4 & 1.0 \\
\hline \multicolumn{10}{|l|}{ Ever fathered a child } \\
\hline Never fathered a child & 94.1 & 92.8 & 86.5 & 92.3 & 94.6 & 87.1 & 92.6 & 94.3 & 88.1 \\
\hline $\begin{array}{l}\text { Have fathered ( } \geq 1 \\
\text { child) }\end{array}$ & 5.9 & 7.2 & 13.5 & 7.7 & 5.3 & 12.9 & 7.5 & 6.7 & 11.9 \\
\hline \multicolumn{10}{|l|}{ Occupation } \\
\hline Unemployed & 10.8 & 27.3 & 26.7 & 1.7 & 15.2 & 18.9 & 8.5 & 20.7 & 18.7 \\
\hline Professional & 4.6 & 11.0 & 4.0 & 4.0 & 7.2 & 2.5 & 5.9 & 9.3 & 5.1 \\
\hline Clerical/Services/Sales & 9.3 & 14.1 & 0.5 & 10.2 & 13.2 & 13.5 & 12.0 & 14.5 & 15.8 \\
\hline Farming & 64.6 & 28.5 & 45.5 & 62.3 & 38.8 & 38.8 & 60.0 & 27.0 & 41.7 \\
\hline Skilled manual & 8.2 & 15.2 & 21.8 & 5.8 & 22.4 & 19.8 & 10.8 & 24.0 & 14.3 \\
\hline Unskilled manual & 2.5 & 3.9 & 1.4 & 4.0 & 3.2 & 3.7 & 2.8 & 4.5 & 4.4 \\
\hline Total & 100.0 & 100.0 & 100.0 & 100.0 & 100.0 & 100.0 & 100.0 & 100.0 & 100.0 \\
\hline
\end{tabular}

The result also revealed that $5-14 \%$ of adolescent boys had fathered at least a child Iin these countries. In 2000/2004, 5.9\%, 5.2\% and $13.5 \%$ of boys were already fathers in Ethiopia, Nigeria and Zambia, respectively. The proportion increased by $21.3 \%$ in Ethiopia but decreased by $7.5 \%$ and $13.4 \%$ in Nigeria and Zambia during 2011/2014. Generally, Zambia recorded the highest proportion of adolescent fatherhood (13.5\%) but consistently decreased across the waves (Table 1). In terms of marital status, the proportion of 'separated' in Zambia among the adolescent decreased from $2.1 \%$, to 1.4 and finally to $1.2 \%$ in wave 1,2 and 3 respectively, while it remained stagnant at $0.4 \%$ in Nigeria since 2005/2008. Ethiopia experienced almost $70 \%$ reduction (from $2.4 \%$ to $1.4 \%$ ) between 2000/2004 and 2005/2008 before it increased to $1.6 \%$ in $2011 / 2014$ (Table 1).

The data on occupation indicated that larger proportions of the adolescent $(60 \%$ in Ethiopia and above $40 \%$ in Zambia) were concentrated in farming job with the exception of Nigeria. Unemployment increased from $10.8 \%$ to $13.7 \%$ between 2000/2004 and 2005/2008 in Ethiopia and later reduced by $5.2 \%$ in $2011 / 2014$. The urban and rural distribution of adolescent males 
indicated a ratio of almost 30:70 (urban/rural) in Ethiopia and Zambia, and 46:54 in Nigeria in $2000 / 2004$. However, the ratio tended towards (40:60) in the last wave for Nigeria and Zambia.

Sexual behaviour among adolescents across SSA (2000-2014): The analysis of age at first sex revealed that $24.4 \%, 36.4 \%$ and $70.0 \%$ have had sexual experience before their $20^{\text {th }}$ birthday in Ethiopia, Nigeria and Zambia, respectively (Table 2). The proportion, however, increased progressively in Ethiopia and Nigeria and Zambia as ages increased. The results also revealed that relatively, $50 \%$ of the adolescents who had cohabited did so within their first 19 years of life, across the three countries surveyed. However, as the proportion of cohabiters shows a downward trend among adolescent aged $\leq 19$, it increased among those aged 20-24 in Nigeria. The statistic remained relatively the same in Zambia (Table 2). One-third of adolescent boys had more than one lifetime sexual partners. Relatively, 7-10\% had also experienced union turnover; $34.1 \%, 45.8 \%$ and $75.4 \%$ were sexually active in Ethiopia, Nigeria and Zambia in the 2000/2004 survey period against $28.4 \%, 41.5 \%$ and $64.6 \%$ in the next survey period $(2005 / 2008)$ and $29.1 \%, 35.3 \%$ and $65.2 \%$ in $2011 / 2014$, respectively. Knowledge of modern contraceptive methods was overwhelming. However, the proportion that had tested for HIV range from only $3.3 \%$ to $6.8 \%$ between 2000 and 2004 in Ethiopia (Table 2). The proportion of male adolescents that used condom in last sex increased from 8.9\% (Ethiopia), 17.5\% (Nigeria) and $18.2 \%$ (Zambia) in 2000/2004, to $9.1 \%$ (Ethiopia), 20.5\% (Nigeria) and 24.7\% (Zambia) in 2011/2014 (Table 2). There was a drastically decrease in the proportion of adolescent male who ever paid for sex across the surveyed countries. The proportions that had experienced genital discharge ranged between $0.2 \%$ in Ethiopia to $4.0 \%$ in Zambia. However, the reduction in genital discharge and ulcer was not general for the three countries. STIs consistently reduced across the three countries though Zambia was most affected from 2000/2004 to 2011/2014 survey period.

The multivariate binary logistic results indicated that age is statistically significant in the likelihood of becoming an adolescent father in both 2005/2008 and 2011/2014. Adolescents in. age group 20-24 were 0.117 and 0.222 times less likely to be adolescent father in 2005/2008 and $2011 / 2014$, respectively, compared to those in the younger age group ( $\leq 19$ years). The probability of adolescent fatherhood decreases with increase in level of education in 2005/2008. Adolescent boy with lower levels of education (primary/secondary) were 1.413 and 1.781 times more likely to be adolescent fathers especially in the 2005/2008 ( $\mathrm{r}$ is positive). The result indicated that adolescents with primary, secondary and tertiary education were $0.379,0.357$ and 0.313 times less likely to be adolescent fathers compared to those with no formal education (the reference category). Being in the professional occupation and farming were statistically significant in $2011 / 2014$ in the likelihood of adolescent fatherhood.

Adolescents from the rural areas are 1.206 times more likely to be adolescent fathers compared to urban residents. Adolescents from middle and rich wealth families were 0.785 and 0.496 times less likely to be adolescent father compared to those from the poor wealth families (Table 3). Those who cohabited at age 20-24 were 3.589 times more likely to experience fatherhood (as adolescents) in 2005/2008 compared to those who experienced the same at lower age. Age at cohabitation was statistically significant at both waves $(p<0.05)$. Multiple sexual partnerships was positively associated with adolescent fatherhood all round the waves analysed. Adolescents with lifetime sexual partner $(\geq 2)$ were $1.673(2005 / 2008)$ and $1.769(2011 / 2014)$ times more likely to be father compared to those with one or no sexual partners. 
Table 2: Sexual behaviour among adolescent in SSA (2000-2014)

\begin{tabular}{|c|c|c|c|c|c|c|c|c|c|}
\hline \multirow{2}{*}{ Sexual behaviour indices } & \multicolumn{3}{|c|}{ 2000-2004 } & \multicolumn{3}{|c|}{$2005-2008$} & \multicolumn{3}{|c|}{$2011-2014$} \\
\hline & Ethio & Nig & Zam & Ethio & Nig & Zam & Ethio & Nig & Zam \\
\hline \multicolumn{10}{|l|}{ Age at 1st Sex } \\
\hline Never had sex & 65.9 & 54.3 & 24.7 & 71.7 & 58.6 & 35.4 & 71.0 & 64.8 & 34.8 \\
\hline$\leq 19$ years & 24.4 & 36.4 & 70.0 & 18.4 & 31.8 & 58.5 & 15.8 & 25.9 & 59.5 \\
\hline 20-24 years & 9.7 & 9.4 & 5.2 & 9.8 & 9.7 & 6.1 & 13.3 & 9.3 & 5.7 \\
\hline \multicolumn{10}{|l|}{ Ever \& age at $1^{\text {st }}$ Cohabitation } \\
\hline$\leq 19$ years & 53.3 & 59.7 & 43.0 & 64.1 & 53.7 & 43.8 & 59.1 & 52.9 & 44 \\
\hline 20-24 years & 46.7 & 40.3 & 57.0 & 35.9 & 46.3 & 56.2 & 40.9 & 47.1 & 56 \\
\hline \multicolumn{10}{|l|}{ Recent sexual activity } \\
\hline Never had sex & 65.9 & 54.3 & 24.7 & 71.7 & 58.6 & 35.4 & 71.0 & 64.8 & 34.8 \\
\hline Active in last 4 weeks & 14.3 & 19.8 & 29.8 & 12.9 & 17.1 & 24.2 & 13.3 & 14.3 & 25.7 \\
\hline Not active in last 4 weeks & 19.8 & 26.0 & 45.4 & 15.5 & 24.4 & 40.4 & 15.8 & 21 & 39.5 \\
\hline \multicolumn{10}{|l|}{ Sexual partner minus wife } \\
\hline Only one partner & 85.3 & 74.2 & 66.5 & 92.4 & 80.4 & 72.6 & 92.0 & 78.8 & 71.9 \\
\hline 2 or more partners & 14.7 & 25.8 & 33.6 & 7.6 & 19.6 & 27.4 & 8.0 & 21.1 & 28.4 \\
\hline \multicolumn{10}{|l|}{ Frequency of Union } \\
\hline Only once & 86.1 & 92.5 & 89.3 & na & 92.9 & 91.2 & 89.9 & 89.9 & 94.3 \\
\hline$\geq 2$ times & 13.9 & 7.5 & 10.7 & na & 7.1 & 8.8 & 10.1 & 10.1 & 5.7 \\
\hline \multicolumn{10}{|l|}{ Contraceptives Knowledge } \\
\hline Know no Methods & 20.9 & 11.4 & 4.6 & 11.0 & 14.7 & 2.4 & 2.8 & 10.7 & 1.2 \\
\hline Modern methods & 78.6 & 88.3 & 95.4 & 88.8 & 85 & 97.6 & 97.1 & 88.8 & 98.7 \\
\hline Other methods & 0.5 & 0.3 & 100 & 0.1 & 0.3 & 100 & 0.1 & 0.5 & 0.1 \\
\hline \multicolumn{10}{|l|}{ Ever heard STIs } \\
\hline No & 9.1 & 4.4 & 2.2 & 4.2 & 8.9 & 0.7 & 1.9 & 7.4 & 0.5 \\
\hline Yes & 90.9 & 95.6 & 97.8 & 95.8 & 91.1 & 99.3 & 98.1 & 92.6 & 99.5 \\
\hline \multicolumn{10}{|l|}{ Ever heard AIDS } \\
\hline No & 10.2 & 4.7 & 3.0 & 5.0 & 9.7 & 0.8 & 2.0 & 8.0 & 0.8 \\
\hline Yes & 89.8 & 95.3 & 97.0 & 95.0 & 90.3 & 99.2 & 98.0 & 92.0 & 99.2 \\
\hline \multicolumn{10}{|l|}{ Ever been tested for HIV } \\
\hline No & 96.7 & 91.8 & 93.2 & 92.3 & 91.5 & 83.7 & 62.4 & 89.7 & 52.9 \\
\hline Yes & 3.3 & 8.2 & 6.8 & 7.7 & 8.5 & 16.3 & 37.6 & 10.3 & 47.1 \\
\hline \multicolumn{10}{|l|}{ Ever paid for sex } \\
\hline No & 95.4 & 95.1 & 80.8 & 98.7 & na & $\mathrm{Na}$ & 98.1 & 97.7 & 91.4 \\
\hline Yes & 4.6 & 4.9 & 19.2 & 1.3 & na & $\mathrm{Na}$ & 1.9 & 2.3 & 8.6 \\
\hline \multicolumn{10}{|l|}{ Use condom in last sex } \\
\hline Not used & 91.8 & 82.5 & 81.8 & 92.3 & 83.4 & 77.3 & 90.9 & 79.5 & 75.3 \\
\hline Used & 8.2 & 17.5 & 18.2 & 7.7 & 16.6 & 22.7 & 9.1 & 20.5 & 24.7 \\
\hline \multicolumn{10}{|l|}{ Had genital discharge } \\
\hline No & 99.2 & 97.8 & 96 & 99.8 & 98.7 & 98.0 & 99.2 & 99 & 98 \\
\hline Yes & 0.8 & 2.2 & 4.0 & 0.2 & 1.3 & 2.0 & 0.8 & 1.0 & 2.0 \\
\hline Total & 100.0 & 100.0 & 100.0 & 100.0 & 100.0 & 100.0 & 100.0 & 100.0 & 100.0 \\
\hline
\end{tabular}

Source: Computed from DHS 2000-2014. ${ }^{*}$ Ethio $=$ Ethiopia, Nig $=$ Nigeria, Zam $=$ Zambia, na $=$ not available 
Table 3: Binary logistic regression illustrating interconnections between selected variables and adolescent fatherhood.

\begin{tabular}{|c|c|c|}
\hline Selected variables & $(2005-2008)$ & (2011-2014) \\
\hline Age group & $\beta, \operatorname{Exp}(B)$ & $\beta, \operatorname{Exp}(B)$ \\
\hline \multicolumn{3}{|l|}{$\leq 19$ years $(\mathrm{RC})$} \\
\hline $20-24$ & $-2.15(0.117)^{* *}$ & $-2.18(0.222) * *$ \\
\hline \multicolumn{3}{|l|}{ Education } \\
\hline \multicolumn{3}{|l|}{ No Education (RC) } \\
\hline Primary Education & $0.35(1.413)$ & $-0.47(0.379)$ \\
\hline Secondary Education & $0.58(1.781)$ & $0.15(0.357)$ \\
\hline Higher Education & $-1.29(0.275)$ & $-0.55(0.313)$ \\
\hline \multicolumn{3}{|l|}{ Occupation } \\
\hline \multicolumn{3}{|l|}{ Unemployed (RC) } \\
\hline Professional & $-1.55(0.213)$ & $-1.06(0.389) * *$ \\
\hline Clerical/Services/Sales & $0.64(1.894)$ & $-0.15(0.510)$ \\
\hline Farming/unskilled & $0.35(1.418)$ & $0.65(0.251) * *$ \\
\hline Skilled manual & $-0.91(0.403)$ & $-0.45(0.294)$ \\
\hline \multicolumn{3}{|l|}{ Religion } \\
\hline \multicolumn{3}{|l|}{ Christianity (RC) } \\
\hline Islam & $-0.55(0.575)$ & $-0.36(0.179) * *$ \\
\hline Others (Traditional) & $-1.61(0.201) * *$ & $-0.43(0.180) * *$ \\
\hline \multicolumn{3}{|l|}{ Residence } \\
\hline \multicolumn{3}{|l|}{ Urban (RC) } \\
\hline Rural & $0.19(1.206)$ & $-0.285(0.184)$ \\
\hline \multicolumn{3}{|l|}{ Wealth status } \\
\hline \multicolumn{3}{|l|}{ Poor wealth status (RC) } \\
\hline Middle wealth status & $-0.24(0.785)$ & $0.41(0.168) * *$ \\
\hline Rich wealth status & $-0.70(0.496) * *$ & $0.28(0.175)$ \\
\hline \multicolumn{3}{|l|}{ Used Condom } \\
\hline \multicolumn{3}{|l|}{ No $(\mathrm{RC})$} \\
\hline Yes & $-0.61(0.547)$ & $-0.24(0.248)$ \\
\hline \multicolumn{3}{|l|}{ Age at first sex } \\
\hline \multicolumn{3}{|l|}{$\leq 19$ years $(\mathrm{RC})$} \\
\hline $20-24$ years & $-0.30(0.743)$ & $0.31(0.198)$ \\
\hline \multicolumn{3}{|l|}{ Age at first cohabitation } \\
\hline \multicolumn{3}{|l|}{$\leq 19$ years $(\mathrm{RC})$} \\
\hline $20-24$ years & $1.28(3.589) * *$ & $1.56(0.136) * *$ \\
\hline \multicolumn{3}{|l|}{ Lifetime sexual partners } \\
\hline \multicolumn{3}{|l|}{ Only one partner (RC) } \\
\hline 2 or more partners & $0.52(1.673)$ & $0.571(1.769)^{* *}$ \\
\hline \multicolumn{3}{|l|}{ Condom use } \\
\hline \multicolumn{3}{|l|}{ Not used (RC) } \\
\hline Used Condom & $-1.01(0.363) * *$ & $-0.07(0.238)$ \\
\hline Constant & $3.416(30.442)$ & $1.29(0.640)$ \\
\hline
\end{tabular}

Source: Computed using DHS Datasets (2000-2014) from 3 countries $* * \mathrm{P} \leq 0.05$

DOI: http://dx.doi.org/10.4314/ejhs.v28i4.9 


\section{DISCUSSION}

The study provided a-14 year wide-ranging empirical analysis of the trends and patterns of adolescent fatherhood in three sub-Saharan Africa countries. The insights from the study identified key determinants of fatherhood among the adolescents in Nigeria, Ethiopia and Zambia as distinct from country-specific study $(7,17,18,21,26-28)$. It has also added to the body of knowledge on the areas of adolescent sexual behaviour and corroborated submissions from other studies that the preponderance of babyfathers is real and could be inimical to the child's health, education, and total wellbeing/welfare of the family $(2,4,19,21,29,30)$. Generally, the finding indicated that the adolescents in the country of the study were engaging in sexual activity that might predispose them to numerous social challenges, including sexual and reproductive health problems (4). The decline in the proportion of male adolescent with multiples sexual partnership $\geq 2$ as well as increase in condom use between the periods studied could be due to increasing sexuality education in the region (31). This change in the impact of primary education on the likelihood of fatherhood in 2010/2015 could be due to massive drive towards free basic education for girls in most parts of subSaharan Africa (32-35). However, the import of household education as significant driver of lowering incidence of adolescent fatherhood could be eroded considering the supremacy of culture on social behaviour including marriages and multiple sexual partnership in sub-Saharan Africa $(8,9,36)$.

However, this study is not without some limitations. The response on ever fathered at least a child is usually subjective because there are often no medical validations. Uncertainty is mostly surrounding paternity responses especially due to multiple sexual partnerships and possibility for men not to know or acknowledge that they have impregnated or fathered a child (15). Besides, biological contribution to the conception of a child may not necessarily imply fatherhood in the social context. There are also challenge of age classification of adolescent but the adopted age range used in this study is located in various international definitions of adolescent.

The study concludes that the significant negative association between primary and tertiary education and adolescent fatherhood could be maximised for policy formulation and implementation. Since adolescents in skilled manual and professional jobs are negatively associated with adolescent fatherhood, it could imply that adolescent empowerment would help in reducing boys' vulnerability to fatherhood and other risks involved. The findings from this study could be explored for policy and programme advocacy towards adolescent empowerment and against adolescent fatherhood. The authors therefore recommend support from policy-takers, governments and other stakeholders towards male adolescent access to both primary and tertiray education. Social workers and health personnel could also explore the opportunity for intense rural and urban campaign against the rising levels of cohabitations notwithstanding the age of adolescent involved.

\section{ACKNOWLEDGEMENTS}

The authors appreciate MEASURE DHS for permission to access the dataset used for this study. Also, the authors wish to thank Covenant University Centre for Research, Innovation and Development (CUCRID) for providing resources and facilities that enhanced the preparation of the manuscript. We also appreciate the review and comments of the participants of SOCIOINT 2017 Conference (DUBAI, UAE) where the paper was first presented in July 2017.

\section{REFERENCES}

1. Bhatasara S, Chevo T, Changadeya T. An Exploratory Study of Male Adolescent Sexuality in Zimbabwe: The Case of Adolescents in Kuwadzana Extension, Harare. J Anthropol. 2013;2013:1-11.

2. Seme A, Wirtu D. Premarital sexual practice among school adolescents in Nekemte Town, East Wollega. Ethiop $J$ Health Dev. 2008;22(2):167-73. 
3. Birhan Z, Tushune K, Jebena MG. Sexual and reproductive health services use, perceptions, and barriers among young people in southwest Oromia, Ethiopia. Ethiop J Health Sci. 2018;28(1):37-48.

4. Ray S, Ghosh T, Mondal PC, Basak S, Alauddin M, Choudhury SM, et al. Knowledge and information on psychological, physiological and gynaecological problems among adolescent schoolgirls of eastern India. Ethiop $J$ Health Sci. 2011;21(3):183-189.

5. Regassa T, Chala D, Adeba E. Premarital sex in the last twelve months and its predictors among students of Wollega University, Ethiopia. Ethiop $J$ Health Sci. 2016;26(4):351-8.

6. Amoo EO. Emerging Teen Fatherhood and its implications for National Development. $J$ Population Assoc Nigeria. 2012;4(1):93-111.

7. Wusu O, Amoo EO. Sub-Saharan African Children and Adolescents. Chapter 11. Contin Change Sub-Sahara Afr Demogr. 2014;192.

8. Awusabo-Asare K, Annim MSK. Wealth status and risky sexual behaviour in Ghana and Kenya. Appl Health Econ Health Policy. 2008;6(1):27-39.

9. Bingenheimer JB. Men's Multiple Sexual Partnerships in 15 Sub-Saharan African Countries: Sociodemographic Patterns and Implications. Stud Fam Plann. 2010;41(1):117.

10. Delius P, Glaser C. The myths of polygamy: a history of extra-marital and multipartnership sex in South Africa. South Afr Hist J. 2004;50(1):84-114.

11. Ikpe EB. Human sexuality in Nigeria: A historical perspective. In Citeseer; 2004. p. 10-38.

12. Slap GB, Lot L, Huang B, Daniyam CA, Zink TM, Succop PA. Sexual behaviour of adolescents in Nigeria: cross sectional survey of secondary school students. Bmj. 2003;326(7379):15.

13. Doyle AM, Mavedzenge SN, Plummer ML, Ross DA. The sexual behaviour of adolescents in sub-Saharan Africa: patterns and trends from national surveys. Trop Med Int Health. 2012;17(7):796-807.

14. Hindin MJ, Fatusi AO. Adolescent sexual and reproductive health in developing countries: an overview of trends and interventions. Int Perspect Sex Reprod Health. 2009;35(2):58-62.

15. Amoo EO, Igbinoba AO, Imhonopi D, Banjo O, Ajaero CK, Akinyemi JO, et al. Trends, Drivers and Health Risks of Adolescent Fatherhood in sub-Saharan Africa. Proc SOCIOINT 2017- 4th Int Conf Educ Soc Sci Humanit 10-12 July 2017- Dubai UAE. 2017;(SOCIOINT 2017):1257-67.

16. Ringheim K, Gribble J. Improving the reproductive health of sub-Saharan Africa's youth. Route Achieve Millenn Dev Goals Wash DC Popul Ref Bur. 2010;

17. Leslie K, Dibden L. Adolescent parents and their children-The paediatrician's role. Paediatr Child Health. 2004;9(8):561.

18. Thornberry TP, Wei EH, Stouthamer-Loeber M, Van Dyke J. Teenage fatherhood and delinquent behavior. US Department of Justice, Office of Justice Programs, Office of Juvenile Justice and Delinquency Prevention; 2000.

19. Murray CE, King K, Crowe A. Understanding and Addressing Teen Dating Violence Implications for Family Counselors. Fam J. 2016;24(1):52-9.

20. Amoo EO, Oni GA, Ajayi MP, Idowu AE, Fadayomi TO, Omideyi AK. Are Men's Reproductive Health Problems and Sexual Behavior Predictors of Welfare? Am J Mens Health. 2017 Vol. 11(3) 487-497

21. Sipsma H., Biello K. B., Cole-Lewis H., Kershaw T. Like father, like son: The intergenerational cycle of adolescent fatherhood. Am J pub health. 2010 Vol. 100(3), 517-52.

22. Martinez GM, Chandra A, Abma JC, Jones J, Mosher WD. Fertility, contraception, and fatherhood: data on men and women from cycle 6 (2002) of the 2002 National Survey of Family Growth. Vital Health Stat 23. 2006;(26):1-142. 
23. Kiernan KE. Becoming a young parent: a longitudinal study of associated factors. $\mathrm{Br} \mathrm{J}$ Sociol. 1997;406-28.

24. National Population Commission. ICF International. Nigeria. Demographic and health survey 2013. Abuja Niger. 2014;

25. National Population Commission, [Nigeria] and ICF International. Integrated Demographic and Health Series (IDHS), version 1.0. Data Extract from NGIR6A.SAV and NGHR6A.SAV, Nigeria Demographic and Health Survey 2013 [Dataset] [Internet]. Minnesota Population Center and ICF International; 2013. Available from: https://www.idhsdata.org/idhs/citation.shtml

26. Kaufman CE, Wet T, Stadler J. Adolescent pregnancy and parenthood in South Africa. Stud Fam Plann. 2001;32(2):147-60.

27. Luke N. Confronting the'sugar daddy'stereotype: age and economic asymmetries and risky sexual behavior in urban Kenya. Int Fam Plan Perspect. 2005;6-14.

28. Rwenge M. Sexual risk behaviors among young people in Bamenda, Cameroon. Int Fam Plan Perspect. 2000;118-30.

29. Fletcher JM, Wolfe BL. The effects of teenage fatherhood on young adult outcomes. Econ Inq. 2012;50(1):182-201.

30. National Fatherhood Initiative. Statistics on the Father Absence Crisis in America National Fatherhood Initiative, Germantown. National Fatherhood Initiative, Germantown; 2016.

31. Boonstra HD. Advancing sexuality education in developing countries: evidence and implications. Evid-Based Approaches Sex Educ Glob Perspect. 2015;14(3):180.

32. African Union. Common African Position (CAP) on the Post-2015 Development Agenda [Internet]. African Union, Addis Ababa, Ethiopia; 2015 [cited 2016 Aug 5]. Available from: http://www.who.int/pmnch/development_age nda.pdf?ua $=1$

33. African Union. AGENDA 2063. Report of the Commission on the African Union Agenda 2063. The Africa We Want in 2063. ASSEMBLY OF THE UNION TwentyFourth Ordinary Session 30 -31 January 2015 Addis Ababa, ETHIOPIA [Internet]. African Union, Addis Ababa, Ethiopia; 2015 [cited 2016 Aug 5]. Available from: http://www.fasngo.org/assets/files/25\%20GI MAC/Final\%20docs/Report\%20of\%20the\%2 0Commission.pdf

34. Department of Internal Relations and Cooperation. Agenda 2063 [Internet]. Diplomatic Training Research and Development (DTRD) Department of International Relations and Cooperation, Republic of South Africa; 2014 [cited 2015 Aug 5]. Available from: http://www.dfa.gov.za/docs/2014/au_agenda 2063 booklet.pdf

35. Panday S, Makiwane M, Ranchod C, Letsoalo T. Teenage pregnancy in South Africa: with a specific focus on school-going learners. Pretoria Dep Basic Educ. 2009;

36. Leclerc-Madlala S. Age-disparate and intergenerational sex in southern Africa: the dynamics of hypervulnerability. Aids. 2008;22:S17-25 